\title{
The Effects of Financial and Political Risks on Economic Risk in Southern European Countries: A Dynamic Panel Analysis
}

\author{
Dervis Kirikkaleli $^{1} \&$ Kelvin Onyibor ${ }^{2}$ \\ ${ }^{1}$ Faculty of Economic and Administrative Science, European University of Lefke, Northern Cyprus, Turkey \\ ${ }^{2}$ Department of Economics, University of Manitoba, Canada \\ Correspondence: Dervis Kirikkaleli, Department of Banking and Finance, Faculty of Economic and Administrative \\ Science, European University of Lefke, Northern Cyprus, TR-10 Mersin, Turkey. Tel: 90-5488-637-770.
}

Received: October 27, 2019

Accepted: November 26, 2019

Online Published: November 29, 2019

doi:10.5430/ijfr.v11n1p381

URL: https://doi.org/10.5430/ijfr.v11n1p381

\begin{abstract}
In this study, we investigate the effects of financial and political risks on the economic risk in Southern European countries. Quarterly data were employed, covering the period from 2000/Q1 to 2015/Q4. We performed the Pedroni Cointegration, Westerlund Cointegration, Common Correlated Estimated Mean Group (CCEMG), and Dynamic Common Correlated Estimated Mean Group technique (dynamic CCEMG). Our empirical findings suggest that (i) an improved financial environment is associated with less economic risk in the Southern European countries; (ii) political risk is harmful to economic stability.
\end{abstract}

Keywords: Southern European countries, economic risk, financial risk, political risk, dynamic CCEMG

JEL Classifications: R11, C33, C58, P16

\section{Introduction}

Europe in general has been drastically transformed as a result of the financial crisis experienced during the early 2000s. Among the affected areas of the world, Southern Europe is a region that has experienced negative effects following this crisis. It is undeniable that southern Europe has subsequently exhibited poor economic performance. Portugal, Spain, Italy, Cyprus and Malta have an estimated total population of over 140 million people, with an estimated combined GDP of $\$ 4.2$ trillion. Pooled together, these countries would be considered as the world's $10^{\text {th }}$ most populated country as well as the $4^{\text {th }}$ largest world economy after the US, China, and Japan.

However, the overall pooled value of these economies is still less compared to its value at the end of 2006 after inflationary adjustments, while a 70\% increase in their combined national debt has also been observed since that time After the impact of the financial crisis, Southern Europe stands as the only world region not to have recorded any economic growth. This is in comparison to its neighbouring countries, which have grown significantly such as; UK $(16 \%)$, Germany (16\%), US (21\%), Japan (6\%), and China (153\%). Southern Europe's major problem is that it is lagging behind the world economies in terms of monetary policy and economic growth. The high level of synchronization in regard to the Central Banks' policies was the primary factor that subdued the negative monetary policy extreme effect after the 2008-2009 global financial and economic crises.

The negative long-term over-spilling effect of this crisis on both economic and social environments has received increased attention among scholars and politicians. However, the effects of political and financial risks on economic risk in Southern European countries have not previously been the subject of in-depth investigation. This study aims to apply newly-developed panel-based econometric techniques to investigate the effects of financial and political risks on economic risk for Southern European countries while controlling for global economic uncertainty, which can also be regarded as global uncertainty, as well as the 2008-2009 global financial and economic crisis. Therefore, the primary goal of this study is to fill this gap in the economic and finance literature by establishing panel-based models. The study will likely open a new debate in the literature, and the findings of this study generate noteworthy implications for policy-makers in the region. In this study, Pedroni Cointegration, Westerlund Cointegration, and dynamic CCEMG techniques are all employed.

From the post-World War II period until the present time, the greatest challenge faced by the global economy and particularly Europe has been the global financial crisis (Cassette and Farvaque, 2014). Furceri and Mourougane (2012) 
argued that the disturbances created in the credit markets coupled with the losses of major credit institutions are the primary causes of the economic slowdown. Based on this, Siddiqui and Qazi (2013) strongly asserted that confidence in financial institutions to meet their financial obligations declined dramatically, leading to an upward trend in political, economic and financial risks. These variables experienced a high level of volatility during that period. These kinds of risks have given rise to stunted economic growth and have created an environment of economic fear.

The paper is organised as follows. The next section explores the existing empirical research associated with economic risk and its relationship with political and financial risk. In the next section, we critically outline our data collection and estimation procedures and present the descriptive statistics of the variables used in this study. The fourth section describes the models, methodology, and proposed tests that are employed in this study, including the cross-sectional dependency test, slope heterogeneity, CIPS unit root test, dynamic CCEMG and both Pedroni and Westerlund Cointegration tests. Subsequently, analysis and discussion of the results are presented in the fifth section. Finally, the paper ends with various conclusions and policy recommendations.

\section{Literature Review}

Domestic and global financial, economic, and political vulnerabilities have encouraged scholars to explore the factors affecting these vulnerabilities; however, in the literature, the effects of financial and political risks on the economic risk of Southern European countries have not been explored in depth. Thus, this research aims to answer the following questions: (1) Do domestic financial and political risks affect the economic risk of the Southern European countries while controlling for global uncertainty and the recent 2008-2009 global financial and economic crisis?; (2) If the answer to this question is yes, what is the nature of the relationship in the long term?; and (3) What are the directions of the causalities within this framework?

In the economic literature, the nexus between economic growth and financial development can be traced back to Schumpeter's (1912) study on the German economy, which gave rise to extensive literature aimed at investigating the finance-based growth hypotheses. He underscored that the allocation of resources has become more efficient through financial deepening, which creates an avenue for the transfer of scarce resources from areas where they are abundant to those that are lagging, thus improving economic growth. Proper documentation of Schumpeter's (1912) arguments was conducted in the studies of Goldsmith (1959), who employed panel regression data from 1970-1999 for 30 developing countries. Chandavarkar (1992) took this a step further to establish a link between economic growth and financial development by employing the time series Autoregressive Redistributed Lag model (ARDL) for the ASEAN-4 (Thailand, Indonesia, Philippines and Malaysia). King and Levine (1993) supported Schumpeter's study by regressing a cross-country analysis of 80 countries over the period of 1960-1989. Levine et al., (2000) also employed a dynamic GMM technique on 74 countries to support Schumpeter's hypothesis. In an attempt to correct the bias control criticism of Levine et al., (2000), Beck et al. (2000) employed a bias-controlled panel technique on the nexus between economic growth, private savings rate and accumulated physical capital and concluded that the positive effects of financial improvement on economic growth can be explained by the fact that it accelerates productivity and facilitates the efficient allocation of resources. Furthermore, Loayza and Ranciere (2006) provided evidence indicating that economic growth and financial depth both have a positive relationship however; the sign of relationship in the short term is negative. In a similar study, Ozturk (2008) found a bidirectional association between financial development and economic growth by conducing Vector autoregression analysis of Turkey for the period from 1975-1996.

In an attempt to further strengthen the study of Ozturk (2008), Cournède and Denk (2015) performed an extensive study on economic growth and financial development in the long run by taking into account the OECD and G20 countries. They argued that financial development increases long-term economic growth by increasing the credibility of assessable loans for investment, enhancing capital allocation efficiency, improving the allocation of resources and enabling costs to be decreased due to higher demand in the market.

Despite all these studies, several other researchers have concluded that the expansion of financial instruments and improvement of the finance sector does not mean that it plays a key role in accelerating economic growth. Rousseau and Wachtel (2011) argued that a significant reduction in the strength of the relationship between financial development and economic growth has been witnessed in recent years as a result of the increasing substitution of equity market for debt financing. This relationship is supported by evidence found by Cecchetti and Kharroubi (2012), who concluded that financial development was not beneficial for economic growth in 50 developed and underdeveloped countries. Arcand et al. (2012) supported the earlier findings of Rousseau and Wachtel (2011) by providing in-depth evidence of the weakening relationship between financial development and economic growth by employing alternative empirical approaches to show that excessive finance has a negative effect on economic growth.

It is widely accepted the factor that makes a developing economy attractive is the level of financial investments it 
makes, particularly if the environment is ideal for the investments, which could then lead to steady growth. Short-term macro-economic policies arise because of political risk; in fact, political risk could rapidly decrease financial risk due to frequent changes in policies. Major studies based on areas of political risk in the financial sector include those by Hibbs (1986), Brown et al. (1988), Cutler et al. (1989), Pantzalis et al. (2000), Li and Born (2006), Bialkowski et al. (2008), Julio and Yook (2012), and Smales (2015). These are some of the studies that have investigated the link between political risk and financial systems.

However, it is evident that political risk is also likely to be harmful to the financial sector, particularly to macro-economic indicators. Hibbs (1986) and Cutler et al. (1989) explored this view. As Hibbs (1986) argued, if the government changes its economic policies, this may cause returns from the stock market to fluctuate from time to time. On the other hand, Cutler et al. (1989) argued that political risk affects the US financial system directly. Pantzalis et al. (2000) used 33 countries' stock markets to explore the range of the valuation of assets in the stock markets during the two-week election period. They concluded that stock prices seemed to increase in the two weeks during which the election was held. Their conclusive report was also supported by Li and Born (2006).

On the other hand, when measuring the economic growth of a nation, it is important to take into account political risk. Political stability helps shape a nation's temporal and permanent decisions. Additionally, political vulnerability is likely to discourage investors, particularly foreign ones. Thus, declining investment in a country contributes to slower economic growth. Olson (1963) extended the research on the effects of political turbulence on the growth of an economy, particularly emerging markets, and highlighted the destructive impact of political risk on economic growth. Similarly, a negative relationship between political risk and economic development was reported by Barro (1991), Alesina and Perotti (1996), Benhabib and Rustichini (1996), Ades and Chua (1997), Devereux and Wen (1998), and Darby et al. (2004), and strong emphasis was placed on the fact that political turmoil results in a decreasing rate of returns on investment, which implies a slowdown in economic growth. Moreover, Bailkowski et al. (2008) measured the impact politics has on financial markets by employing data from 27 OECD countries. The results from this analysis showed that economic risk indices could significantly fluctuate during the period around an Election Day. Pastor and Veronesi (2013) contended that economic and political fluctuations have strong implications on the risk premium by measuring the effect of political risk in the financial market in Australia and reported that because of high political risk, the financial market was significantly affected. Furthermore, Aisen and Veiga (2010) proposed that economic growth is adversely affected by changing macro-economic policies. Employing the GMM estimator for linear dynamic panel models covering the period between 1960-2004 for 169 countries, Aisen and Veiga (2010) discovered that an increasing level of political risk would lead to decreasing economic growth.

Tabassam (2016) used four indicators-terrorism, election, regime and strikes-to measure political risk and concluded that only terrorism had a significant negative effect on the vulnerability of Pakistan's economy using both ARCH and GARCH models. More recently, Sausgruber, Sonntag and Tyran (2019) highlighted that democratisation increases GDP per capita by about 20 percent in the long term. They also found that the positive effects of democratisation do not change in countries with different development levels.

Apart from the effects of domestic political and financial factors on a country's economic performance, Rodrick (2012) observed that "policymakers need to guard against not just domestic shocks, but also shocks that emanate outward from financial risk elsewhere". Li et al. (2012) explored the spill-over effect of the 2008-2009 global financial and economic crises on the Chinese economy. They emphasized that despite a dramatic reduction in Chinese exports during the 2008-2009 global financial and economic crisis, China's economic growth performance remained above the international average. By using Bayesian VAR models and spectral analysis over the period of 1988-2013 in Sweden, Stockhammar and Österholm (2016) found that Swedish economic growth was negatively affected by US policy uncertainty.

Kirikkaleli (2019) investigate the linkage between economic risk and financial risk in Greece between 1990 and 2018 using wavelet coherence approach. He finds that financial risk has significant impact on political economic risk. In addition, Kirikkaleli (2016) aims to examine the relationship among the country risk variables for seven Balkan countries using first generation panel techniques, namely Pedroni cointegration test, FMOLS and DOLS. The outcome of Kirikkaleli (2016) reveals that financial stability has a long-run effect on the political stability whereas financial stability and economic stability affect each other positively in the long-run in the Balkan countries. Using ARDL, DOLS and Markov Switching tests, Kirikkaleli (2018) aims to explore the effects of domestic risk and foreign risk factors on the stock market index in Taiwan. The study reveals that while there is long-run linkage between risk and stock market index, stock market index in Taiwan is positively affected by declining economic, political and financial risks. However, the effects of political and financial risks on economic risk in Southern European countries 
have not previously been the subject of in-depth investigation. This present study aims to apply Pedroni Cointegration, Westerlund Cointegration, and dynamic CCEMG techniques to explore the effects of financial and political risks on economic risk for Southern European countries while controlling for global economic uncertainty, which can also be regarded as global uncertainty, as well as the 2008-2009 global financial and economic crisis. Therefore, the primary goal of the present study is to fill this gap in the economic and finance literature by establishing panel-based models.

\section{Data}

In this study, we aim to explore the effects of financial and political risk on the economic risk of Southern European countries, by controlling for the 2008-2009 global financial and economic crises. In the econometric analysis, economic risk, political risk, and financial risk are used from the PRS Group. Moreover, global economic policy uncertainty in this study is used as a proxy for global uncertainty and is collected from Economic Policy Uncertainty, while the 2008-2009 global financial and economic crises (dummy variable) is constructed by the authors. This data was constructed on a quarterly basis from 2000/Q1 to 2015/Q4. The time series variables used in the models are shown below:

Economic Risk (ER): The economic risk rating seeks to evaluate the present level of economic strengths and weaknesses of a country. The variables indexed in this risk rating are as follows: inflation rate, per capita GDP, budget balance (\% of GDP), real GDP growth rate and current account (\% of GDP). All three risk rating indexes are solely evaluated based on numerical facts and performance. A more detailed structure of the risk index variables and assessment methodology can be found in the manual of the PRS Group.

Political Risk (PR): The political risk rating is comprised of 12 weighted variables, which portray both social and political characteristics to ensure a more robust coverage of political risk contents; this risk rating is calculated using casual assumptions, expert judgment and weights. The level of political stability remains the major reason for measuring political risk of any given country; hence, we measure this political risk by allocating points in a risk structure to a pre-designed group of variables, which are collectively termed as the component of political risk. The risk components and weights that constitute political risk are: Socioeconomic conditions, government stability, external and internal conflict, investment profile (each having 12 points); law and order, corruption, ethnic tensions, military in politics, democratic accountability (each having 6 points); quality of bureaucracy (4 points), which adds up to a total of 100 points.

Financial Risk (FR): Assessing the potential of a country to settle its incurred debts is the major goal that the financial risk rating seeks to achieve. In a more detailed explanation, the financial risk assessment entails a country's capacity to offset its debt obligations ranging from official, commercial to trade debts. Relative to political risk, financial risk tends to measure the trust and credibility level of a country; however, FR focuses on the financial aspect. Similar to political risk, related variables are summed up in a pre-designed weighted group. The variables include: foreign debt stock ( $\%$ of GDP), foreign debt service payment (\% of GDP), exchange rate risk and net international liquidity.

Global Uncertainty (GR): The global economic policy uncertainty index is constructed by Economic Policy Uncertainty and measured by using the GDP-weighted average of national EPU indices for 20 countries, namely Australia, Brazil, Canada, Chile, China, France, Germany, Greece, India, Ireland, Italy, Japan, Mexico, the Netherlands, Russia, South Korea, Spain, Sweden, the United Kingdom, and the United States.

Table 1. Data and descriptive statistics

\begin{tabular}{|c|c|c|c|c|}
\hline Period & 2000Q1-2015Q4 & & & \\
\hline Variable & Economic Risk Index & Financial Risk Index & Political Risk Index & Global Uncertainty \\
\hline Source & Political Risk Services & Political Risk Services & $\begin{array}{l}\text { Political } \\
\text { Services }\end{array}$ & Economic Policy \\
\hline Code & ER & FR & PR & GR \\
\hline Mean & 35.801 & 35.874 & 78.430 & 103.130 \\
\hline Median & 36.333 & 36.000 & 79.333 & 102.001 \\
\hline Maximum & 42.500 & 43.500 & 90.000 & 185.302 \\
\hline Minimum & 25.000 & 26.666 & 64.500 & 55.167 \\
\hline
\end{tabular}




\begin{tabular}{lllll}
\hline Std. Dev. & 3.428 & 3.523 & 5.882 & 32.581 \\
\hline Jarque-Bera & 25.026 & 0.930 & 14.032 & 21.768 \\
\hline Probability & 0.000 & 0.627 & 0.000 & 0.000 \\
\hline Observations & 384 & 384 & 384 & 384 \\
\hline
\end{tabular}

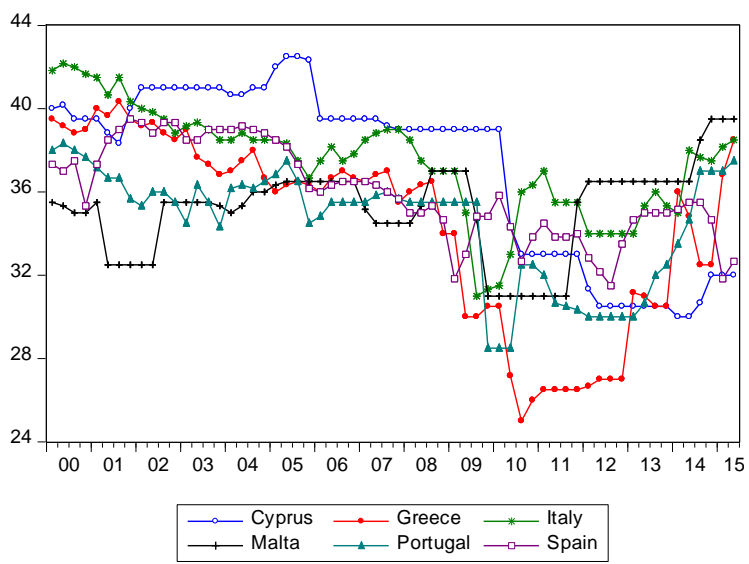

Figure 1. Economic risk index

Source: ICRG

Based on the data set constructed by the International Country Risk Guide (ICRG), the six Southern European countries that are examined in this study are Greece, Italy, Portugal, Cyprus, Malta and Spain, which are categorised as medium to low risk based on their economic, financial and political environments between 2000 and 2015. As clearly shown in Figure 1, Italy and Spain are the most stable countries, sitting between the very low to low risk category based on their economic, financial and political risk environments. Greece's performance was the poorest in all risk ratings among the Southern European countries, thus making it the most vulnerable country in terms of risk in this study. One of the major reasons for Greece's poor performance compared to other Southern European countries was the devastating financial, debt and political crises the country had faced in previous decades. The 2008-2009 global financial and economic crisis triggered the already existing vulnerabilities in those economies, hence placing them in the moderate risk category as opposed to the high-risk position of developed countries.

\section{Methodology}

Since our purpose for undertaking this research is to analyse the effects of political and financial risk on the economic risk for the aforementioned Southern European countries, we constructed two separate models (with and without controlling variables-global uncertainty and 2008-2009 global financial and economic crisis), which are presented in Equations (1) and (2).

$$
\begin{gathered}
\mathrm{ER}_{\mathrm{it}}=\lambda_{1 \mathrm{i}} d_{t}+\alpha_{1 \mathrm{i}} \mathrm{FR}_{\mathrm{it}}+\alpha_{2 \mathrm{i}} \mathrm{PR}_{\mathrm{it}}+u_{\mathrm{it}} \\
u_{i t}=\theta_{i} f_{t}+\varepsilon_{i t}, \mathrm{i}=1,2, \ldots, \mathrm{N} \text { and } \mathrm{t}=1,2, \ldots \mathrm{T} \\
\mathrm{ES}_{\mathrm{it}}=\lambda_{2 \mathrm{i}} d_{t}+\alpha_{3 \mathrm{i}} \mathrm{FR}_{\mathrm{it}}+\alpha_{4 \mathrm{i}} \mathrm{PR}_{\mathrm{it}}+\alpha_{5 \mathrm{i}} \mathrm{GR}_{\mathrm{it}}+\alpha_{6 \mathrm{i}} \mathrm{DUM}_{\mathrm{it}}+u_{\mathrm{it}} \\
u_{i t}=\theta_{i} f_{t}+\varepsilon_{i t}, \mathrm{i}=1,2, \ldots, \mathrm{N} \text { and } \mathrm{t}=1,2, \ldots \mathrm{T}
\end{gathered}
$$

where $u_{i t}$ represents the residual term. $d_{t}$ and $f_{t}$ denote observed and unobserved common effects. In a normal standard econometric analysis procedure, the cross-sectional dependency test is applied. O'Connell (1998) stressed the need to check for cross-sectional dependence (CD), insisting that ignoring CD could lead to over-rejection of the hypothesis of a panel unit root. Furthermore, he identified that ignoring CD could result in biased and inconsistent outcomes. Resultantly, Pesaran's (2004) cross-sectional dependency (CD) test and Pesaran, Ullah, and Yamagata's (2008) bias-adjusted Lagrange Multiplier test were employed as a preliminary step. Pesaran, Ullah, and Yamagata 
(2008) pointed out that the CD test is very effective when T > N in a panel structure. Similarly, the bias-adjusted test acts as a robustness check in data with structural breaks and non-normality of errors and also contains corrective measures against biases when $\mathrm{N}>\mathrm{T}$. Hence, employing both tests in our analysis will strengthen the reliability of our results, and they have been tested under the null hypothesis of no cross-sectional dependency (Colombage, 2009).

In an estimation where the slope homogeneity assumption is violated, these estimation techniques become biased (Blackburne and Frank 2007). Pesaran and Yamagata (2008) stated that slope heterogeneity has a high likelihood of occurrence in a panel with large N and T. In this study, Pesaran and Yamagata's (2008) slope heterogeneity test is applied. The test takes into consideration the presence of cross-sectional dependence to investigate the presence of slope heterogeneity in our panel. The test is superior because it introduces a more advanced structure of the Swamy test (Swamy 1970), which has the potential to cover a larger time dimension (T) and cross-section (N) (Juhl and Lugovskyy 2014).

Next, we checked the order of integration of the time series variables using the CIPS test proposed by Pesaran (2007). The test is strictly aligned with the $\operatorname{AR}(p)$ equation, which takes into consideration both the present and lagged values of the mean dependent variable $y_{i t}$

$$
\bar{y}_{\mathrm{it}}=\alpha_{\mathrm{i}}+\gamma_{\mathrm{i}} \mathrm{y}_{\mathrm{it}-1}+\cdots \gamma_{\mathrm{i}} \mathrm{y}_{\mathrm{it}}-\mathrm{p}+\delta_{\mathrm{i} 0} \bar{y} \mathrm{t}+\delta_{\mathrm{i} 1} \bar{y}_{\mathrm{t}-1}+\cdots+\delta_{\mathrm{ip}} \bar{y}_{\mathrm{t}-\mathrm{p}}+\varepsilon_{\mathrm{it}}
$$

We went further to transform Equation (4) into a cross-section average and first difference in the dependence variable to obtain the CIPS statistics. Hence, for each cross-section, individual ADF statistics $\left(\mathrm{CADF}_{i}\right)$ have been computed.

$$
C I P S=\frac{\sum_{i=1}^{N} C A D F_{i}}{N}
$$

Hence, the hypothesis of unit root can be stated as:

Ho: $\beta_{\mathrm{i}}=0$ for each individual cross section

Against the possible alternatives,

$$
\mathrm{H}_{\mathrm{i}}: \beta_{\mathrm{i}}<0, i=1,2, \ldots N_{1}, \beta_{\mathrm{i}}=0, i=N_{1}+1, N_{1}+2, \ldots N
$$

However, the critical values of the CIPS and its corresponding individual $\mathrm{CADF}_{i}$ can only be obtained from Monte Carlo simulation (Pesaran, 2007) for different values of $\mathrm{T}$ and $\mathrm{N}$ as a result of non-normal distribution in the CIPS and $\mathrm{CADF}_{i}$ panel statistics.

To investigate the long-term equilibrium relationship between economic risk and financial and political risk in the Southern European countries, we used the new generation panel co-integration test developed by Westerlund (2008), which is based on the Error Correction Model. The Westerlund Cointegration test allows for varieties of heterogeneity and also generates p-values that are robust against cross-sectional dependence. Westerlund (2008) constructed a null hypothesis of no error correction that when rejected means that there is a cointegration relationship among the variables. In addition, as a robust test for the Westerlund cointegration test, we employed the cointegration test developed by Pedroni (2001). The cointegration test allows for heterogeneity in the autoregressive term.

Since cross-sectional dependency and slope heterogeneity were found in our model, we employed Pesaran and Chudik's (2015) dynamic CCEMG to investigate the effects of financial and political risk on the economic risk of the selected Southern European countries. Pesaran (2006) first proposed this technique, which was later advanced by Kapetanios et al. (2011). The main mechanism behind this technique that differentiates it from the earlier CCEMG test is the fact that the lagged values of the dependent variable and cross-sectional mean are added as explanatory variables in the model. In addition, the dynamic CCEGM creates room to accommodate structural breaks in our series. The Dynamic CCEGM according to Pesaran and Chudik (2015) is estimated as follows:

$$
y_{i t}=\alpha_{0 i} y_{i t-1}+\alpha_{1 i}+\beta_{i} x_{i t}+\sum_{j=1}^{n} \delta_{i} \bar{y}_{i t-1}+\sum_{j=1}^{n} \theta_{i} \bar{x}_{i t-1}+\varphi_{i} f_{t}+\varepsilon_{i t}
$$

Where $y_{i t}$ is the dependent variable, $\alpha_{1 i}$ is the time-invariant group fixed effects, $x_{i t}$ represents the vector containing the independent variables, $\bar{y}_{i t-1}$ and $\bar{x}_{i t-1}$ are cross sectional averages lagged values, $\beta_{i}$ is the individual country slope on the observable regressor, $\varphi_{i} f_{t}$ represents the slope heterogeneous unobserved common factor, while $\varepsilon_{i t}$ stands for the error term.

Equation (6) is estimated by employing Ordinary Least Square for individual cross-sections while controlling for 
autocorrelation and heteroskedasticity (Newey-West 1987). Taking averages of individual coefficients over each regression would result in the CCEGM estimator. This equation is estimated as follows:

$$
\text { CCEMG }=N^{-1} \sum_{i=1}^{N} \hat{\beta}_{i}
$$

Where $\hat{\beta}_{i}$ represents the estimated coefficients.

\section{Empirical Finding}

To accomplish our aim in this study, as a first step, we investigated the cross-sectional dependency properties of the time series variables by employing the Langrange Multiplier (LM) test, the Bias-Adjusted LM test, and LM and CD test for both Models 1 and 2. Table 2 presents the outcomes of the cross-sectional dependency tests. The outcomes clearly reveal that the null hypothesis of no cross-sectional dependence can be rejected at the 5\% level, implying that cross-sectional dependencies exist in both models. Each of the Southern European country has similar economic dynamics, and this is in line with our expectations. Therefore, we employ Pesaran and Yamagata's (2008) slope heterogeneity test. Table 4 presents the results, which prove our expectation while confirming the existence of both slope heterogeneity and the spatial effect among the panel of six South European countries.

Table 2. Cross sectional dependence result

\begin{tabular}{ll}
\hline & Statistics \\
\hline LM & Model 1. ER = f (FR, PR) \\
\hline Bias Adjusted LM Test & $105.1^{*}$ \\
\hline LM CD & $70.02^{*}$ \\
\hline LM & $8.009^{*}$ \\
\hline Bias Adjusted LM Test & Model 2. ER = f (FR, PR, GR, DUM) \\
\hline LM CD & $111.1^{*}$ \\
\hline
\end{tabular}

Note: $*,{ }^{\mathrm{A}}$ and ${ }^{\mathrm{B}}$ denote $1 \%, 5 \%$ and $10 \%$ significance levels, respectively. The null hypothesis shows no cross-sectional dependence.

Table 3. Slope heterogeneity test result

\begin{tabular}{|c|c|}
\hline & Value \\
\hline & Model 1. ER = f (FR, PR) \\
\hline Swamy $\widehat{S}$ & $179.194^{*}$ \\
\hline$\widetilde{\Delta}$ & $36.424 *$ \\
\hline$\widetilde{\Delta}_{a d j}$ & $37.961 *$ \\
\hline$\widehat{\Delta}$ & $34.128 *$ \\
\hline \multirow[t]{2}{*}{$\widehat{\Delta}_{\text {adj }}$} & 0.577 \\
\hline & Model 2. ER = f (FR, PR, GR, DUM) \\
\hline Swamy $\widehat{S}$ & $199.012 *$ \\
\hline$\widetilde{\Delta}$ & $32.553^{*}$ \\
\hline$\widetilde{\Delta}_{a d j}$ & $34.528^{*}$ \\
\hline$\widehat{\Delta}$ & $25.260 *$ \\
\hline$\widehat{\Delta}_{a d j}$ & 0.433 \\
\hline
\end{tabular}

Note: ${ }^{*},{ }^{\mathrm{A}}$ and ${ }^{\mathrm{B}}$ denote $1 \%, 5 \%$ and $10 \%$ significance levels respectively. Null hypothesis: Presence of slope homogeneity. 
Performing traditional unit root tests when there is a cross-sectional dependence in the time series is likely to be inefficient (Topcu and Payne 2018; Aslan and Nazlioglu 2018; Shahbaz et al. 2018). Thus, we perform the CIPS unit root test to capture the order of integration of the time series variables. The test is constructed based on the assumption of cross-sectional dependence. Before investigating the long-term equilibrium relationship using the Pedroni (2001) and Westerlund (2008) cointegration tests in Models 1 and 2, all the variables should be integrated of order one. Therefore, as a group, a long-term equilibrium linkage may exist. The outcomes of the CIPS unit root test results are reported in Table 4 and show that the variables have a unit root at the 5\% level and are stationary at their first-order differentials.

Table 4. CIPS unit root test results

\begin{tabular}{lll}
\hline & At Level & \\
\hline ER & Constant & Constant + Trend \\
\hline FR & -1.747 & -2.247 \\
\hline PR & $-2.064^{\mathrm{B}}$ & -2.203 \\
\hline GR & -1.731 & -2.274 \\
\hline & $2.061^{\mathrm{B}}$ & 1.700 \\
\hline ER & At First Difference & \\
\hline FR & $-5.952^{*}$ & $-6.070^{*}$ \\
\hline PR & $-5.833^{*}$ & $-5.938^{*}$ \\
\hline GR & $-5.864^{*}$ & $-5.965^{*}$ \\
\hline
\end{tabular}

Note: $*,{ }^{\mathrm{A}}$ and ${ }^{\mathrm{B}}$ denote $1 \%, 5 \%$ and $10 \%$ significance levels, respectively. The null hypothesis for the CIPS unit root test indicates that the time series variable has a unit root.

Obtaining the the same integration of order of variables - I(1) - allows detection of a long-term equilibrium relationship. In this study, we use the Westerlund cointegration test based on the Error Correction Model proposed by Westerlund (2008) and the Pedroni Cointegration test developed by Pedroni (2001). Table 5 presents the outcomes from these cointegration tests. The majority of statistical tests in both cointegration tests reject the null hypothesis that no long-term equilibrium relationship exists among the variables for both models. In other words, economic, financial and political risks have a long-term relationship in the Southern European economies.

Table 5. Panel co-integration test results

\begin{tabular}{|c|c|c|c|c|c|c|c|}
\hline \multicolumn{8}{|c|}{ Model 1. ER = f (FR, PR) } \\
\hline & \multicolumn{4}{|c|}{ Pedroni Cointegration Test } & \multicolumn{3}{|c|}{ Westerlund Cointegration Test } \\
\hline & \multicolumn{7}{|c|}{ (within-dimension) } \\
\hline & Statistic & P-value & $\begin{array}{l}\text { Weighted } \\
\text { Statistic }\end{array}$ & P-value & Statistic & Value & $\begin{array}{l}\text { Robust } \\
\text { P-value }\end{array}$ \\
\hline Panel v-Statistic & 2.225 & $0.013^{\mathrm{A}}$ & -1.897 & 0.971 & $\mathrm{Gt}$ & -2.590 & $0.020^{\mathrm{A}}$ \\
\hline Panel rho-Statistic & -1.364 & $0.086^{\mathrm{B}}$ & -2.259 & $0.011^{\mathrm{A}}$ & $\mathrm{Ga}$ & -11.054 & $0.020^{\mathrm{A}}$ \\
\hline Panel PP-Statistic & -1.320 & $0.093^{\mathrm{B}}$ & -2.220 & $0.013^{\mathrm{A}}$ & $\mathrm{Pt}$ & -5.074 & 0.180 \\
\hline \multirow[t]{3}{*}{ Panel ADF-Statistic } & -1.682 & $0.049^{\mathrm{A}}$ & -2.220 & $0.013^{\mathrm{A}}$ & $\mathrm{Pa}$ & -10.567 & $0.047^{\mathrm{A}}$ \\
\hline & between & mension & & & & & \\
\hline & & Statistic & Prob. & & & & \\
\hline Group rho-Statistic & & -1.558 & $0.059^{\mathrm{B}}$ & & & & \\
\hline
\end{tabular}




\begin{tabular}{|c|c|c|c|c|c|c|c|}
\hline Group PP-Statistic & & -2.050 & $0.020^{\mathrm{A}}$ & & & & \\
\hline Group ADF-Statistic & & -2.021 & $0.021^{\mathrm{A}}$ & & & & \\
\hline \multicolumn{8}{|c|}{ Model 2. ER $=f(F R, P R, G R, D U M)$} \\
\hline & \multicolumn{4}{|c|}{ Pedroni Cointegration Test } & \multicolumn{3}{|c|}{ Westerlund Cointegration Test } \\
\hline & \multicolumn{7}{|c|}{ (within-dimension) } \\
\hline & & & Weighted & & Statistic & Value & Robust \\
\hline & Statistic & P-value & Statistic & P-value & & & P-value \\
\hline Panel v-Statistic & 2.473 & $0.006 *$ & -1.897 & 0.971 & Gt & -2.644 & $0.018^{\mathrm{A}}$ \\
\hline Panel rho-Statistic & -1.431 & $0.076^{\mathrm{B}}$ & -2.989 & $0.001 *$ & $\mathrm{Ga}$ & -10.672 & $0.012^{\mathrm{A}}$ \\
\hline Panel PP-Statistic & -1.366 & $0.086^{\mathrm{B}}$ & -2.619 & $0.004 *$ & $\mathrm{Pt}$ & -5.170 & $0.050^{\mathrm{A}}$ \\
\hline \multirow[t]{3}{*}{ Panel ADF-Statistic } & -1.155 & 0.123 & -2.220 & $0.013^{\mathrm{A}}$ & $\mathrm{Pa}$ & -10.009 & $0.030^{\mathrm{A}}$ \\
\hline & \multicolumn{7}{|c|}{ between-dimension } \\
\hline & & Statistic & Prob. & & & & \\
\hline Group rho-Statistic & & -1.952 & $0.025^{\mathrm{A}}$ & & & & \\
\hline Group PP-Statistic & & -2.286 & $0.011^{\mathrm{A}}$ & & & & \\
\hline Group ADF-Statistic & & -1.824 & $0.034^{\mathrm{A}}$ & & & & \\
\hline
\end{tabular}

Note: $*{ }^{\mathrm{A}}$ and ${ }^{\mathrm{B}}$ denote $1 \%, 5 \%$ and $10 \%$ significance levels, respectively.

In this study, a dynamic CCEMG estimator, which is an extended version of CCCEMG, was used to capture the effects of political and financial risk on economic risk. The technique accounts for slope heterogeneity using mean group instead of pooled regression and allows for cross-section correlation. Table 6 reports the findings for dynamic CCEMG for Models 1 and 2. As presented in Table 6, the models involve the lagged values of the dependent variable -ES (-1) -, which is found to be positive and significant at 5\% in both Models 1 and 2. The result implies that a rise in the initial level of economic risk would result in a subsequent increase in the future level of economic risk in the Southern European countries. Obtaining positive and significant financial risk coefficients in both Model 1 (without controlling for global uncertainty and the 2008-2009 global financial and economic crisis) and Model 2 (with controlling for global uncertainty and 2008-2009 global financial and economic crisis) supports the finance-led growth hypothesis from the risk perspective as well. This finding underscores how financial risk in the Southern European countries is important for predicting economic risk. Moreover, Table 6 reports significant and positive PS coefficients in both models, implying that a better political environment in the Southern European countries is associated with less economic risk. This finding supports the politic-led growth hypothesis and is in alignment with previous findings (Barro 1991; Acemoglu et al. 2003; Julio and Yook 2012; Pastor and Veronesi 2013; Asher and Novosad 2017).

Table 6. Dynamic CCEMG test results

\begin{tabular}{lll}
\hline & Model 1. ER = f(ER(-1), FR, PR) & Model 2. ER = f(ER(-1), FR, PR, GR, DUM) \\
\hline ECM & $-0.067<-3.735>^{*}$ & $-0.123<-2.234>^{\mathrm{A}}$ \\
\hline ER(-1) & $0.536(0.000)^{*}$ & $0.491(0.000)^{*}$ \\
\hline FR & $0.286(0.006)^{*}$ & $0.348(0.014)^{\mathrm{A}}$ \\
\hline PR & $0.016(0.047)^{\mathrm{A}}$ & $0.040(0.000)^{*}$ \\
\hline GR & & $-0.001(0.351)$ \\
\hline DUM & & $-0.013(0.963)$ \\
\hline C & $0.261(0.338)$ & $0.334(0.604)$
\end{tabular}

Note: *, ${ }^{\mathrm{A}}$ and ${ }^{\mathrm{B}}$ denote $1 \%, 5 \%$ and $10 \%$ significance levels, respectively. $\mathrm{C}$ denotes a constant coefficient. The numbers between ( ) and <> represent p-values and t-stats, respectively. ECM denotes the error correction term for the estimated models. As expected, the coefficients of ECM are negative and statistically significant at $5 \%$ level. 


\section{Conclusion}

At the end of the 2000s, the economies of Southern European countries contracted as a result of the global financial crisis. The lack of empirical evidence on the effects of financial and political risks on economic risk in the literature is one of the primary factors that motivated us to conduct this study. Therefore, it is very important for policy-makers to identify whether domestic financial and political risks affect economic risk in the six Southern European countries: Greece, Italy, Portugal, Cyprus, Malta and Spain. In this study, we applied newly-developed techniques, namely Pedroni Cointegration, Westerlund Cointegration, dynamic CCEMG, CCEMG, and quarterly data from the ICRG covering the period of 2000/Q1 to 2015/Q4 are used. We performed the Pedroni Cointegration, Westerlund Cointegration, and dynamic CCEMG techniques. Our findings reveal that (i) economic, financial and political risks have a long-term relationship in the Southern European economies; (ii) an improved financial environment is associated with less economic instability; (iii) political instability is harmful for economic risk; and (iv) over the selected period in these economies, the 2008-2009 global financial and economic crisis had little or no impact on economic risk, which is consistent with Levine et al. (2002), who, based on their analysis of financial intermediate and growth, opined that a crisis on a global scale has little or no impact on the economy of a particular country.

Resultantly, the empirical findings clearly underline the importance of both domestic political and financial risks for economic risk in the Southern European countries. Based on these empirical and consistent findings, we suggest that policy-makers should minimise political and financial risks in their countries in order to either improve the economic environment or accelerate economic development. More specifically, (i) policy-makers should concentrate on foreign debt, liquidity, trade, and exchange rate, which are likely to affect the economic risk levels in Southern European countries; thus it is necessary to control these indicators to minimize the economic risk in these countries; (ii) to avoid possible vulnerability in the macro dynamics, policymakers should also control the main components of the political risk index, namely government stability, bureaucratic quality, internal and external conflicts, religious and ethnic problems, investment profiles, socioeconomic conditions, democratic accountability, and law and order.

Although this study provides strong and consistent empirical findings for the Southern European countries, further research should consider how to advance this argument by focusing on different global regions and also including more control variables such as inflation, exchange rate and interest rate, which would help illuminate the degree and depth of this relationship.

\section{References}

Acemoglu, D., Johnson, S., Robinson, J., \& Thaicharoen, Y. (2003). Institutional causes, macroeconomic symptoms: volatility, crises and growth. Journal of Monetary Economics, 50(1), 49-123. https://doi.org/10.1016/S0304-3932(02)00208-8

Aisen, M. A., \& Veiga, M. F. J. (2011). How does political instability affect economic growth? (No. 11-12). International Monetary Fund. https://doi.org/10.5089/9781455211906.001

Allen, W. A., \& Wood, G. (2006). Defining and achieving financial stability. Journal of Financial Stability, 2(2), 152-172. https://doi.org/10.1016/j.jfs.2005.10.001

Arcand, J. L., Berkes, E., \& Panizza, U. (2012). Too Much Finance?, International Monetary Fund. IMF Working Papers, 161.

Asher, S., \& Novosad, P. (2017). Politics and local economic growth: Evidence from India. American Economic Journal: Applied Economics, 9(1), 229-73. https://doi.org/10.1257/app.20150512

Aslan, M., \& Nazlioglu, S. (2018). Do International Relative Commodity Prices Support the Prebisch-Singer Hypothesis? A Nonlinear Panel Unit Root Testing. Journal for Economic Forecasting, (1), 76-92.

Barro, R. J. (1991). Economic growth in a cross section of countries. The Quarterly Journal of Economics, 106(2), 407-443. https://doi.org/10.2307/2937943

Benhabib, J., \& Rustichini, A. (1996). Social conflict and growth. Journal of Economic Growth, 1(1), $125-142$. https://doi.org/10.1007/BF00163345

Blackburne, E. F., \& Frank, M. W. (2007). Estimation of nonstationary heterogeneous panels. Stata Journal, 7(2), 197. https://doi.org/10.1177/1536867X0700700204

Boyreau-Debray, G. (2003). Financial intermediation and growth: Chinese style. The World Bank. https://doi.org/10.1596/1813-9450-3027

Brown, K. C., Harlow, W. V., \& Tinic, S. M. (1988). Risk aversion, uncertain information, and market efficiency. 
Journal of Financial Economics, 22(2), 355-385. https://doi.org/10.1016/0304-405X(88)90075-X

Cassette, A., \& Farvaque, E. (2014). Are elections debt brakes? Evidence from French municipalities. Economics Letters, 122(2), 314-316. https://doi.org/10.1016/j.econlet.2013.12.022

Cecchetti, S., \& Kharroubi, E. (2012). Reassessing the impact of finance on growth. BIS Working Papers No. 381, Bank for International Settlements.

Chakraborty, I. (2008). Does financial development cause economic growth? The case of India. South Asia Economic Journal, 9(1), 109-139. https://doi.org/10.1177/139156140700900105

Chandavarkar, A. (1992). Of finance and development: neglected and unsettled questions. World Development, 20(1), 133-142. https://doi.org/10.1016/0305-750X(92)90142-I

Chudik, A., \& Pesaran, M. H. (2015). Common correlated effects estimation of heterogeneous dynamic panel data models with weakly exogenous regressors. Journal of Econometrics, 188(2), 393-420. https://doi.org/10.1016/j.jeconom.2015.03.007

Colombage, S. R. (2009). Financial markets and economic performances: Empirical evidence from five industrialized economies. Research in International Business and Finance, 23(3), 339-348. https://doi.org/10.1016/j.ribaf.2008.12.002

Cournède, B., \& Denk, O. (2015). Finance and economic growth in OECD and G20 countries. https://doi.org/10.2139/ssrn.2649935

Cutler, D. M., Poterba, J. M., \& Summers, L. H. (1989). International evidence on the predictability of stock returns. Unpublished manuscript, MIT.

Darby, J., Li, C. W., \& Muscatelli, V. A. (2004). Political uncertainty, public expenditure and growth. European Journal of Political Economy, 20(1), 153-179. https://doi.org/10.1016/j.ejpoleco.2003.01.001

Demetriades, P. O., \& Hussein, K. A. (1996). Does financial development cause economic growth? Time-series evidence from 16 countries. Journal of Development Economics, 51(2), 387-411. https://doi.org/10.1016/S0304-3878(96)00421-X

Demetriades, P. O., \& S. H. Law. (2006). Finance, Institutions and Economic Development. International Journal of Finance and Economics, 11(3), 245-260. https://doi.org/10.1002/ijfe.296

Devereux, M. B., \& Wen, J. F. (1998). Political instability, capital taxation, and growth. European Economic Review, 42(9), 1635-1651. https://doi.org/10.1016/S0014-2921(97)00100-1

Furceri, D., \& Mourougane, A. (2012). The effect of financial crises on potential output: New empirical evidence from OECD countries. Journal of Macroeconomics, 34(3), 822-832. https://doi.org/10.1016/j.jmacro.2012.05.010

Goldsmith, R. W. (1969). Financial Structure and Development. New Haven', CT: Yale University Press.

Greenwood, J., \& Smith, B. D. (1997). Financial markets in development, and the development of financial markets. Journal of Economic Dynamics and Control, 21(1), 145-181. https://doi.org/10.1016/0165-1889(95)00928-0

Julio, B., \& Yook, Y. (2012). Political uncertainty and corporate investment cycles. The Journal of Finance, 67(1), 45-83. https://doi.org/10.1111/j.1540-6261.2011.01707.x

Kapetanios, G., Pesaran, M. H., \& Yamagata, T. (2011). Panels with non-stationary multifactor error structures. Journal of Econometrics, 160(2), 326-348. https://doi.org/10.1016/j.jeconom.2010.10.001

King, R. G., \& Levine, R. (1993). Finance and growth: Schumpeter might be right. The Quarterly Journal of Economics, 108(3), 717-737. https://doi.org/10.2307/2118406

Kirikkaleli, D. (2016). Interlinkage between economic, financial, and political risks in the Balkan countries: Evidence from a panel cointegration. Eastern European Economics, 54(3), 208-227. https://doi.org/10.1080/00128775.2016.1168704

Kirikkaleli, D. (2018). The effect of domestic and foreign risks on an emerging stock market: A time series analysis. The North American Journal of Economics and Finance. https://doi.org/10.1016/j.najef.2018.11.005

Kirikkaleli, D. (2019). Time-frequency dependency of financial risk and economic risk: evidence from Greece. Journal of Economic Structures, 8(1), 37. https://doi.org/10.1186/s40008-019-0173-Z

Knack, S., \& Keefer, P. (1995). Institutions and economic performance: cross-country tests using alternative institutional measures. Economics \& Politics, 7(3), 207-227. https://doi.org/10.1111/j.1468-0343.1995.tb00111.x 
Levine, R., Loayza, N., \& Beck, T. (2000). Financial intermediation and growth: Causality and causes. Journal of Monetary Economics, 46(1), 31-77. https://doi.org/10.1016/S0304-3932(00)00017-9

Li, J., \& Born, J. A. (2006). Presidential election uncertainty and common stock returns in the United States. Journal of Financial Research, 29(4), 609-622. https://doi.org/10.1111/j.1475-6803.2006.00197.x

Liang, Q., \& J.-Z. Teng. (2006). Financial Development and Economic Growth: Evidence from China, China Economic Review, 17(4), 395-411. https://doi.org/10.1016/j.chieco.2005.09.003

Loayza, N., \& Ranciere, R. (2006). Financial Development, Financial Fragility, and Growth. Journal of Money Credit and Banking, 38(4), 1051-1076. https://doi.org/10.1353/mcb.2006.0060

Londregan, J. B., \& Poole, K. T. (1990). Poverty, the coup trap, and the seizure of executive power. World Politics, 42(2), 151-183. https://doi.org/10.2307/2010462

Lucas, R. E. (1988). On the Mechanics of Economic Development. Journal of Monetary Economics, 22(1), 3-42. https://doi.org/10.1016/0304-3932(88)90168-7

Mark, N. C., \& Sul, D. (2003). Cointegration Vector Estimation by Panel DOLS and Long-Run Money Demand. Oxford Bulletin of Economics \& Statistics, 65(5), 655-80. https://doi.org/10.1111/j.1468-0084.2003.00066.x

McKinnon, R. I. (1973). Money and Capital in Economic Development. Washington, DC: Brookings Institution.

Newey, W. K., \& West, K. D. (1987). Hypothesis testing with efficient method of moments estimation. International Economic Review, 1, 777-787. https://doi.org/10.2307/2526578

O'Connell, P. G. (1998). The overvaluation of purchasing power parity. Journal of International Economics, 44(1), 1-19. https://doi.org/10.1016/S0022-1996(97)00017-2

Odhiambo, N. M. (2008). Financial Depth, Savings and Economic Growth in Kenya: A Dynamic Causal Linkage. Economic Modelling, 25(4), 704-13. https://doi.org/10.1016/j.econmod.2007.10.009

Olson, M. (1963). Rapid growth as a destabilizing force. The Journal of Economic History, 23(4), 529-552. https://doi.org/10.1017/S0022050700109210

Pantzalis, C., Stangeland, D. A., \& Turtle, H. J. (2000). Political elections and the resolution of uncertainty: the international evidence. Journal of Banking \& Finance, 24(10), 1575-1604. https://doi.org/10.1016/S0378-4266(99)00093-X

Pastor, L., \& P. Veronesi. (2013). Political Uncertainty and Risk Premia. Journal of Financial Economics, 110(3), 520-545. https://doi.org/10.1016/j.jfineco.2013.08.007

Pedroni, P. (2001). Purchasing Power Parity Tests in Cointegrated Panels. Review of Economics and Statistics, 83(4), 727-731. https://doi.org/10.1162/003465301753237803

Pesaran, M. H. (2004). General diagnostic tests for cross section dependence in panels. Econometrica, 42(4), $155-165$.

Pesaran, M. H. (2006). Estimation and inference in large heterogeneous panels with a multifactor error structure. Econometrica, 74(4), 967-1012. https://doi.org/10.1111/j.1468-0262.2006.00692.x

Pesaran, M. H. (2007). Simple panel unit root test in the presence of cross-section dependence. Journal of Applied Econometrics, 22(2), 265-312. https://doi.org/10.1002/jae.951

Pesaran, M. H., Ullah, A., \& Yamagata, T. (2008). A bias-adjusted LM test of error cross-section independence. The Econometrics Journal, 11(1), 105-127. https://doi.org/10.1111/j.1368-423X.2007.00227.X

Rajan, R. G., \& Zingales, L. (1998). Financial Dependence and Growth. American Economic Review, 88(3), 559-586.

Robinson, J. (1952). The Generalization of the General Theory. In The Rate of Interest and Other Essays. London, UK: Macmillan.

Rousseau, P. L., \& P. Wachtel. (2011). What Is Happening to the Impact of Financial Deepening on Economic Growth?. Economic Inquiry, 49(1), 276-288. https://doi.org/10.1111/j.1465-7295.2009.00197.x

Sausgruber, R., Sonntag, A., \& Tyran, J. R. (2019). Disincentives from Redistribution: Evidence on a Dividend of Democracy. https://doi.org/10.2139/ssrn.3398138

Schumpeter, J. A. (1912). Theorie der Wirtschaftlichen Entwicklung (The Theory of Economic Development). Cambridge, MA: Harvard University Press. 
Shahbaz, M., Shahzad, S. J. H., Mahalik, M. K., \& Sadorsky, P. (2018). How strong is the causal relationship between globalization and energy consumption in developed economies? A country-specific time-series and panel analysis. Applied Economics, 50(3), 1479-1494. https://doi.org/10.1080/00036846.2017.1366640

Siddiqui, D. A., \& Qazi, M. A. (2013). The Effect of Institutions on Economic Growth: A Global Analysis Based on GMM Dynamic Panel Estimation. Structural Change and Economic Dynamics, 24, 18-33. https://doi.org/10.1016/j.strueco.2012.12.001

Smales, L. A. (2015). Better the devil you know: The influence of political incumbency on Australian financial market uncertainty. Research in International Business and Finance, 33, 59-74. https://doi.org/10.1016/j.ribaf.2014.06.002

Swamy, P. A. (1970). Efficient inference in a random coefficient regression model. Journal of the Econometric Society, 7, 311-323. https://doi.org/10.2307/1913012

Topcu, M., \& Payne, J. E. (2018). Further evidence on the trade-energy consumption nexus in OECD countries. Energy Policy, 117, 160-165. https://doi.org/10.1016/j.enpol.2018.03.007

Waqabaca, C. (2004). Financial Development and Economic Growth in Fiji. Working Paper, Reserve Bank of Fiji.

Westerlund, J. (2008). Panel cointegration tests of the Fisher effect. Journal of Applied Economics, 23, 193-233. https://doi.org/10.1002/jae.967

Yorucu, V., \& Bahramian, P. (2015). Price modelling of natural gas for the EU-12 countries: Evidence from panel cointegration. Journal of Natural Gas Science and Engineering, 24, 464-472. https://doi.org/10.1016/j.jngse.2015.04.006

Zang, H., \& Kim, Y. C. (2007). Does Financial Development Precede Growth? Robinson and Lucas Might Be Right. Applied Economic Letters, 14(2), 115-19. https://doi.org/10.1080/13504850500425469 